\title{
Changes of washing water during debittering and the brine during storage of irradiated olive fruits (Olea europea. L.)
}

\author{
By M. Al- Bachir
}

\author{
Radiation Technology Department, Atomic Energy Commission of Syria \\ P. O. Box 6091، Damascus
}

\begin{abstract}
RESUMEN
Cambios en las aguas de lavado durante el desamargor y en la saimuera durante el almacenamiento de aceitunas irradiadas (Olea europea L.).

Aceitunas (Olea eurcpea L.) tratadas con $0,1,2$ y 3 kGy de irradiación gamma se les eliminó el amargor en agua destiada durante 8 dias y se almacenaron en salmuera durante 12 meses a temperatura ambiante. Se determinaron los contenidos sólidos disueltos incrgánicos y los totales, ef $\mathrm{Na}$, el K, el Ca, la conductvidad electrica y los valores de pH en las aguas de lavado (diariamente) y on la salmuera (después de 6 y 12 meses). Los resultados mostraron que la irradiación gamma aumentó los sol. dos disueltos inorgánioos y totales, el Na y el $\mathrm{K}$ en las aguas de lavado, y en la saimuera durante todo el procoso de eliminación dal amarpor asi como durante el periodo do almacenamiento. Además, la irradiación gamma tuvo un electo sobre la conductividad electrica y los valores de pH de las aguas de lavado y de la saimuera.
\end{abstract}

PALABRAS-CLAVE: Aceilung - Agua do lavado - Almacenamiento - Desamargor - firradición gamma.

\section{SUMMARY}

Changes of washing water during debittering and the brine during storage of irradlated olive fruits (Olea europea. L.).

Olive fruits (Olea europes. var. Surramy) treated with $0,1,2$ and $3 \mathrm{kGy}$ of gamma irradiation were debittered in distilled water for 8 days and stored in brine for 12 months at room temperature. Total dissolved and inorganic dissolved solids, $\mathrm{Na}, \mathrm{K}, \mathrm{Ca}$. electric conductivity (EC) and $\mathrm{pH}$ values were evaluated in washing wastewater (daily), and in brine (atter 6 and 12 months). The results showed that gamma irradiation increased the total and inorganic dissolved solids, $\mathrm{Na}$ and $\mathrm{K}$ in washing wastewater, and in brine throughout debittering and storage petiods. Also, gamma irradiation had an offect on $\mathrm{EC}$ and $\mathrm{pH}$ values of washing wastewater and beine.

KEYWOADS: Debittering - Gamma-imadiation - Ohe fruit - Storage - Washing water.

\section{INTRODUCTION}

Table olives are currently the most important fermented fruit product in the Mediterranean basin. Estimated world production for the 1994/1995 seasons is in excess of 900.000 tons (Anonymous, 1994).
Olive has been known in Syria for a long time with an average annual production for the last ten years of about 470 thousand tons (Annual Agricultural Statistical Abstract, 1999). Syria is one of the largest five producer countries in the world, and it was the fourth largest producer of table olives in the world in 1990 (IOOC, 1960 to 1990).

Table olives, can be defined as a product in which preparation and preservation are carried out by a combination of lye treatments, salting and fermentation and/ or acidification, (Fernandez Diez, 1984).

Olive industry faces major problems through contribution to environmental pollution with the wastes produced during the main processing steps such as lye treatment, washing and brining (Fernandez Diez, 1991, Garrido Fernandez, 1982, Fernandez Diez et al., 1985, Garcia et al., 1990).

The application of gamma irradiation to improve fruits storability has been studied from the standpoint of controlling certain physiological disorders as well as reducing spoilage caused by microorganisms (Al-Bachir, 1998, 1999a,b).

Irradiation with gamma rays, when used alone to improve storability, may have affected the firmness of fruits (Al-Bachir, 1998). The softening in fruit maybe attributed to the effect of irradiation on large pectin and polysaccharides such as protopectin and cellulose or to a change of insoluble pectic materials to soluble forms (Kertesz et al., 1964, Al- Bachir, 1986).

Little work has been carried out to study the feasibility of employing gamma irradiation for the preparation or preservation of table olives.

Therefore, the present study aims to investigate the effect of gamma irradiation on chemical characteristics of washing water of table olive fruits, which are used as indicators for debittering, and following the changes in brine throughout storage period. Surrany variety has been used, because it's the major table olive variety in Syria.

\section{MATERIAL AND METHODS}

Fruits of Surrany variety were harvested in the second week of November 1997 from commercial orchards in Idleb (Northern Syria). One Kg of fruits 
were transferred into paper bags, and were irradiated on the second day of harvest. with 0, 1, 2 and 3 kGy of gamma irradiation from a ${ }^{60} \mathrm{Co}$ source (dose rate $669 \mathrm{~Gy} / \mathrm{hr}$.). The absorbed dose was determined using alcoholic chlorobenzen dosimeter (Cserep et al., 1971). Each treatment had four replicates (1 Kg fruits each). The irradiated and unirradiated olives were kept in polyethylene jars with distilled water (1L water for $1 \mathrm{~kg}$ fruits). Water was changed daily up to 8 days for debittering. Then olives were placed in brine, which consisted of $5.6 \% \mathrm{w} / \mathrm{v}$ sodium chloride and stored for 12 months at room temperature.

Four replicates (200 g each) were used to determine the fruit weight and flesh to stone ratio by dividing the total weight to the total number of fruits. Four replicates (1 $\mathrm{Kg}$ each) were used to determine the oil content by grounding the fruits through $3-4$ $\mathrm{mm}$ grinder plate, then extraction of oil by centrifugation at $4000 \mathrm{rpm}$ for 20 minutes was performed. Total and inorganic dissolved solids, Na, K and $\mathrm{Ca}$ contents, $\mathrm{pH}$ and electric conductivity (EC) values were determined in washing wastewater ( 8 washings) and in brine (after 6 and 12 months of storage). According to the method of AOAC (1990), $25 \mathrm{~g}$ solution (washing water or brine) were weighed and dried for $6 \mathrm{hrs}$ at $105^{\circ} \mathrm{C}$ to determine the total dissolved solids. The same samples were dried for 4 hrs at $550^{\circ} \mathrm{C}$ to determine the inorganic dissolved solids. Concentrations of $\mathrm{Na}, \mathrm{K}$ and $\mathrm{Ca}$ cations were determined by adding lithium chloride to the solution using a Swiss flame photometer Model ATS 200 $\mathrm{MKI}, \mathrm{pH}$ values of the solutions were estimated using a $\mathrm{pH}$ meter (Hanna instruments $\mathrm{HI}$ 8521), and electric conductivity EC values were estimated using the TDS/ Conductivity meter (Syber scan 200).

The experiment consisted of four treatments in a completely randomized design with four replicates. The data were subjected to the analysis of variance (ANOVA) using the super ANOVA computer package (Abacus Concepts, Inc, Version 1.11 6/20/91). A separation test on treatment means was conducted using Fisher's least significant difference PLSD at the $95 \%$ confidence level.

\section{RESULTS}

Main characteristics of Surrany olive fruits used in this study were: greenish- black, medium- sized fruits (1.8 $\pm 0.12 \mathrm{~g} /$ fruit), and oil content of about (14.59 \pm $2.28 \%)$. The pulp accounted for $(80.36 \pm 1.39 \%)$ of fruit weight and the endocarp for the remainder. The ratio of flesh to stone is $5: 1$.

\subsection{Effect of gamma irradiation on dissolved solids in washing water and brine}

Table I shows that all used doses of gammairradiation (1, 2 and 3KGy) significantly increased ( $p<$ 0.05 ) total dissolved solids in the washing water on the second, third, fourth and fifth days of washing. The total dissolved solids produced from irradiated fruits, throughout the washing period ( 8 washings), were significantly higher than those produced from unirradiated ones.

Data in Table I show that gamma irradiation did not affect total dissolved solids throughout the storage period (6 and 12 months).

Table I

Effect of gamma irradiation on total dissolved organic matter in washing water and brine of olive fruits ( $\mathrm{g} / \mathrm{kg}$ fruits)

\begin{tabular}{|c|c|c|c|c|c|c|c|c|c|c|c|}
\hline \multirow{2}{*}{ Treat } & \multicolumn{9}{|c|}{ Washing waler $\mid \mathrm{da} y)$} & \multicolumn{2}{|c|}{ Brine } \\
\hline & $1 s t$ & 2 nd & 3 rd & 4 th & 5 th & 6 th & 7 th & 8 th & total & 6 months & 12 months \\
\hline Control & $0.42 \mathrm{a}$ & $0.58 \mathrm{a}$ & $0.86 \mathrm{a}$ & $1.40 \mathrm{a}$ & $1.71 \mathrm{a}$ & $1.90 \mathrm{ab}$ & $1.98 \mathrm{a}$ & $3.41 \mathrm{c}$ & $12.25 \mathrm{a}$ & $41.45 \mathrm{a}$ & $68.15 a$ \\
\hline $1 \mathrm{kGy}$ & $0.46 \mathrm{a}$ & $0.75 \mathrm{~b}$ & $1.27 \mathrm{~b}$ & $1.96 \mathrm{~b}$ & $2.06 \mathrm{~b}$ & $1.99 \mathrm{~b}$ & $1.98 \mathrm{a}$ & $3.20 \mathrm{~b}$ & $13.68 \mathrm{bc}$ & $42.6 .2 \mathrm{a}$ & $78.05 \mathrm{a}$ \\
\hline $2 \mathrm{kGy}$ & $0.42 \mathrm{a}$ & $0.86 \mathrm{c}$ & $1.35 \mathrm{~b}$ & $1.98 \mathrm{~b}$ & $1.96 \mathrm{~b}$ & $1.85 \mathrm{a}$ & $1.95 \mathrm{a}$ & $2.89 \mathrm{~b}$ & $13.27 \mathrm{~b}$ & $42.90 \mathrm{a}$ & $7 B .26 a$ \\
\hline $3 \mathrm{kGy}$ & $0.52 \mathrm{a}$ & $0.97 \mathrm{~d}$ & $1.53 \mathrm{c}$ & $2.23 \mathrm{c}$ & $2.06 \mathrm{~b}$ & $1.88 \mathrm{ab}$ & $1.85 \mathrm{a}$ & $3.17 \mathrm{~b}$ & $14.19 \mathrm{c}$ & $42.47 \mathrm{a}$ & $69.53 \mathrm{a}$ \\
\hline
\end{tabular}

Values within a column followed by the sarne loter are not significantly diflerent at the $95 \%$ contidence level.

Table II shows the effect of gamma irradiation on inorganic dissolved solids in washing water of olive fruits through 8 washings, and in brine after 6 and 12 months of storage. These results revealed that irradiation with 1,2 and 3 kGy resulted in an increased amount of inorganic dissolved solids in washing water for the second, third and fourth washing water. There are no significant differences in inorganic dissolved solids between irradiated and unirradiated for 1st, 5th and 6th washing water. However, at the end of washing period, irradiation decreased significantly the inorganic dissolved matters (2 and 3 KGy for the 7 th washing and 1 and $2 \mathrm{KGy}$ for the 8 th washing). The total release of inorganic dissolved solids produced from irradiated fruits through the washing periods (8 washing) was 
Table II

Effect of gamma irradiation on dissolved inorganic matter in washing water and brine of olive fruits ( $\mathrm{g} / \mathrm{kg}$ fruits)

\begin{tabular}{|c|c|c|c|c|c|c|c|c|c|c|c|}
\hline \multirow{2}{*}{ Treat. } & \multicolumn{9}{|c|}{ Washing waiter |day) } & \multicolumn{2}{|c|}{ Brine } \\
\hline & 1st & 2 nd & $3 r d$ & 4 th & 5 th & 6 th & 7 th & 8 th & total & 6 months & 12 menths \\
\hline Contral & $0.30 \mathrm{a}$ & $0.25 \mathrm{a}$ & 0.37 a & व80 a & $1.06 \mathrm{a}$ & $0.83 a$ & $1.11 \mathrm{c}$ & $1.93 \mathrm{c}$ & $6.67 \mathrm{a}$ & $36.72 \mathrm{a}$ & $64.80 \mathrm{a}$ \\
\hline $1 \mathrm{kGy}$ & $0.28 \mathrm{a}$ & $0.30 \mathrm{~b}$ & $0.48 \mathrm{~b}$ & $1.05 \mathrm{~b}$ & $1.10 \mathrm{a}$ & $0.80 \mathrm{a}$ & $1.09 b c$ & $1.81 \mathrm{~b}$ & $6.91 \mathrm{a}$ & 38.11 в & $74.17 a$ \\
\hline $2 \mathrm{kGy}$ & 0.24 a & $0.37 \mathrm{c}$ & $0.58 \mathrm{C}$ & $1.09 \mathrm{~b}$ & $1.11 \mathrm{a}$ & $0.81 \mathrm{a}$ & $0.91 \mathrm{a}$ & $1.72 \mathrm{a}$ & $6.82 \mathrm{a}$ & $38.2 . \mathrm{d}_{\mathrm{a}}$ & $74.25 a$ \\
\hline $3 \mathrm{kGy}$ & $0.31 \mathrm{a}$ & $0.49 \mathrm{~d}$ & $0.72 \mathrm{~d}$ & $1.28 \mathrm{c}$ & $1.07 \mathrm{a}$ & $0.82 a$ & $0.95 \mathrm{ab}$ & $1.95 \mathrm{c}$ & $7.59 \mathrm{~b}$ & $37.99 \mathrm{a}$ & $66.06 \mathrm{a}$ \\
\hline
\end{tabular}

Values within a column followed by the same letter are not significantly diterent at the $95 \%$ contidence level.

higher than those produced from unirradiated ones, with only the $3 \mathrm{KGy}$ treatment had a significant effect. Throughout the storage period (6 and 12 months), the differences in inorganic dissolved solids in brine between irradiated and unirradiated treatments were not significant.

\subsection{Effect of gamma irradiation on mineral charges in washing water and brine}

Table III shows that sodium in washing water of irradiated fruits was significantly $(P<0.05)$ higher than that of unirradiated ones in the first and the second wash for fruits treated with 2 kGy, the fourth wash for fruits with treated $1 \mathrm{kGy}$, and in the sixth wash for fruits treated with 3 kGy compared to the control. After 8 washings the total sodium content in washing water of irradiated fruits was higher than those of the unirradiated ones, with only the 3 kGy treatment has a significant difference. However, sodium content in the brine of irradiated fruits with 2 kGy were significantly higher than those of unirradiated ones after 6 months of storage. Whereas, there were no significant differences in calcium content in brine between irradiated and unirradiated fruits after 12 months of storage.

As shown in Table IV, almost all used doses of gamma irradiation significantly $(P<0.05)$ increased potassium in the washing water in the second and fourth washing times. Whereas, only 1 and 3 KGy increased significantly $(P<0.05)$ potassium in the fifth and sixth washing times. After 8 washings the total potassium in washing water of irradiated fruits was significantly higher than those of unirradiated fruits. Throughout the storage period, the potassium content in brine was significantly $(P<0.05)$ higher in the irradiated treatment with $3 \mathrm{kGy}$ after 6 months of storage, and with $1 \mathrm{kGy}$ after 12 months of storage than that the control.

Table $V$ shows that gamma irradiation significantly decreased $(P<0.05)$ calcium dissolution from fruit in washing water more than the control at the first and fourth and the total washing periods ( 8 washings). However, calcium content in the brine of irradiated fruits with 2 and 3 kGy were significantly higher than those of unirradiated ones after 6 months of storage. Whereas, there were no significant differences in calcium content in brine between irradiated and unirradiated fruits after 12 months of storage.

Table III

Effect of gamma irradiation on sodium $(\mathrm{Na})$ charge in washing water and brine of olive fruits ( $\mathrm{mg} / \mathrm{Kg}$ fruits)

\begin{tabular}{|c|c|c|c|c|c|c|c|c|c|c|c|}
\hline \multirow{2}{*}{ Treat, } & \multicolumn{9}{|c|}{ Washing water (day) } & \multicolumn{2}{|c|}{ Brine } \\
\hline & 1st & 2 nd & 3 rd & 4 th & Sth & 6 th & 7 th & 8 th & total & 6 months & 12 months \\
\hline Control & $8.27 \mathrm{a}$ & $8.60 \mathrm{c}$ & $13.73 \mathrm{a}$ & 15.15 a & $15.92 \mathrm{a}$ & $8.77 \mathrm{~b}$ & $1.61 \mathrm{~b}$ & $8.12 \mathrm{~b}$ & $80.16 a$ & 408 a & 743 a \\
\hline $1 \mathrm{kG}$ & 8.78 a & 6.54 a & $15.18 \mathrm{a}$ & $18.97 \mathrm{~b}$ & $19.24 \mathrm{a}$ & $8.79 \mathrm{~b}$ & $0.80 \mathrm{a}$ & 7.25 a & $85.55 a b$ & 418 ab & 846 a \\
\hline $2 \mathrm{kGy}$ & $9.78 \mathrm{~b}$ & $10.25 d$ & $13.79 \mathrm{a}$ & $16.98 a b$ & $18.61 \mathrm{a}$ & 7.99 a & $0.80 \mathrm{a}$ & $6.48 \mathrm{a}$ & $84.69 a b$ & $430 \mathrm{~b}$ & 921 a \\
\hline 3 kGy & $8.26 a$ & $7.63 \mathrm{~b}$ & $16.00 \mathrm{a}$ & $17.45 \mathrm{ab}$ & $17.51 \mathrm{a}$ & $10.67 \mathrm{C}$ & $0.81 \mathrm{a}$ & 8. $34 \mathrm{~b}$ & $86.67 b$ & $422 a b$ & $674 a$ \\
\hline
\end{tabular}

Values within a column followod by the same letter are not significantly different at the $95 \%$ confidenoe lewel. 
Table IV

Effect of gamma irradiation on potasium (K) charge in washing water and brine of ollive fruits/mn/ Kn fruitel

\begin{tabular}{|c|c|c|c|c|c|c|c|c|c|c|c|}
\hline \multirow{2}{*}{ Treal. } & \multicolumn{9}{|c|}{ Washing water (day) } & \multicolumn{2}{|c|}{ Brine } \\
\hline & 1st & 2 nd & $3 \mathrm{rd}$ & $4^{\text {th }}$ & 5 th & 6 th & 7 th & 8 th & botal & 6 months & 12 manths \\
\hline Control & 85 a & $103.53 \mathrm{a}$ & $170 \mathrm{a}$ & $175 \mathrm{a}$ & $285 \mathrm{a}$ & $192 \mathrm{a}$ & $220 \mathrm{c}$ & $276 \mathrm{c}$ & $1506 \mathrm{a}$ & $286 a$ & $373 a$ \\
\hline $1 \mathrm{kG} y$ & $91 \mathrm{a}$ & $146.59 \mathrm{c}$ & $179 a$ & $224 \mathrm{~b}$ & $295 \mathrm{~b}$ & $205 \mathrm{~b}$ & $217 \mathrm{~b}$ & $270 \mathrm{~b}$ & $1631 \mathrm{c}$ & $282 \mathrm{a}$ & $491 \mathrm{~b}$ \\
\hline $2 k G y$ & $87,70 \mathrm{a}$ & 141 b & $173 \mathrm{a}$ & $236 \mathrm{c}$ & $286 \mathrm{a}$ & $194 \mathrm{a}$ & $210 \mathrm{a}$ & $255 \mathrm{a}$ & $1583 \mathrm{~b}$ & 293 a & $344 a$ \\
\hline $3 \mathrm{kG}$ & $105 \mathrm{~b}$ & $173 d$ & $187 \mathrm{a}$ & $245 \mathrm{~d}$ & 297 b & $205 \mathrm{~b}$ & $222 \mathrm{c}$ & $274 c$ & $1707 d$ & $428 \mathrm{~b}$ & $392 a b$ \\
\hline
\end{tabular}

Values within a column folowed by the same letter are not signilicantly different at the $96 \%$ confidence level.

Table V

Effect of gamma irradiation on calcium (Ca) charge in washing water and brine of olive fruits ( $\mathrm{mg} / \mathrm{Kg}$ fruits)

\begin{tabular}{|c|c|c|c|c|c|c|c|c|c|c|c|}
\hline \multirow{2}{*}{ Treat } & \multicolumn{9}{|c|}{ Wasking wales (day) } & \multicolumn{2}{|c|}{ Brine } \\
\hline & $18 \mathrm{st}$ & 2 nd & 3 rd & 4 th & 5 th & 6 th & 7 th & 8 th & total & 6 months & 12 months \\
\hline Control & $36.47 \mathrm{c}$ & $9.776 \mathrm{a}$ & $17.53 \mathrm{a}$ & $11.63 \mathrm{~b}$ & $4.98 \mathrm{a}$ & $9.97 \mathrm{a}$ & $0.00 \mathrm{a}$ & $0.00 \mathrm{a}$ & $90.33 \mathrm{c}$ & $55.6 \mathrm{a}$ & 315 a \\
\hline $1 \mathrm{kGy}$ & 27.45 b & $9.817 \mathrm{a}$ & $15.81 \mathrm{a}$ & $8.33 \mathrm{ab}$ & $4.99 a$ & $9.98 \mathrm{a}$ & $0.00 \mathrm{a}$ & $0.00 \mathrm{a}$ & $76.37 \mathrm{~b}$ & $56.0 \mathrm{a}$ & 364 a \\
\hline $2 \mathrm{kGy}$ & $27.50 \mathrm{~b}$ & 9.857 a & $15.73 \mathrm{a}$ & 4.98 a & $4.98 \mathrm{a}$ & $9.98 \mathrm{a}$ & $0.00 \mathrm{a}$ & $0.00 \mathrm{a}$ & $73.02 \mathrm{~b}$ & $65.8 \mathrm{~b}$ & 299 a \\
\hline $3 \mathrm{kGy}$ & $18.23 \mathrm{a}$ & $9.867 \mathrm{a}$ & $15.83 \mathrm{a}$ & $6.61 \mathrm{a}$ & $4.98 \mathrm{a}$ & $10.00 \mathrm{a}$ & $0.00 \mathrm{a}$ & $0.00 \mathrm{a}$ & $65.51 \mathrm{a}$ & $66.0 \mathrm{~b}$ & $260 \mathrm{a}$ \\
\hline
\end{tabular}

Values within a column followod by the same letter are not significantly ditlerent at the $95 \%$ confidence level.

\subsection{Effect of gamma irradiation on $\mathrm{pH}$ and $E C$ values of washing water and brine}

Table VI shows that high doses of gamma irradiation increased EC values at the first three washings. Whereas, the same doses tended to decrease the values at the last three washing times in comparison with the control.

No significant differences were observed in the $\mathrm{EC}$ of brine of irradiated and unirradiated fruits after 6 months of storage. Whereas, 3 kGy treatment tended to increase it significantly $(P<0.05)$ in comparison with the control after 12 months of storage.

Table VII shows that gamma irradiation showed a trend of increasing $\mathrm{pH}$ value through the last four washing times.

Although not significant, the high doses of gamma irradiation tended to increase the $\mathrm{pH}$ values throughout the storage period (6 and 12 months).

Table VI

Effect of gamma irradiation on EC value in washing water and brine of olive fruits $(\mathrm{ms} / \mathrm{c})$

\begin{tabular}{|c|c|c|c|c|c|c|c|c|c|c|}
\hline \multirow{2}{*}{ Treat. } & \multicolumn{8}{|c|}{ Washing water (day) } & \multicolumn{2}{|c|}{ Beine } \\
\hline & Ist & 2 nd & 3 nd & 4 th & 5th & 6 th & 7 th & 8 th & 6 months & 12 months \\
\hline Comtrol & $0.49 \mathrm{bc}$ & $0.40 \mathrm{a}$ & 0.51 a & $0.71 \mathrm{a}$ & 0.84 a & $0.88 \mathrm{~b}$ & $0.89 \mathrm{~b}$ & $1.38 \mathrm{~b}$ & $56.83 \mathrm{a}$ & $57.63 \mathrm{a}$ \\
\hline $1 \mathrm{kGy}$ & $0.48 \mathrm{ab}$ & $0.45 a b$ & $0.64 \mathrm{~b}$ & $0.87 \mathrm{a}$ & $0.91 \mathrm{bc}$ & $0.89 \mathrm{~b}$ & $0.89 \mathrm{~b}$ & $1.37 \mathrm{~b}$ & $56.53 \mathrm{a}$ & $57.47 \mathrm{a}$ \\
\hline $2 \mathrm{kGy}$ & $0.44 \mathrm{a}$ & $0.48 \mathrm{~b}$ & $0.67 \mathrm{~b}$ & $0.69 \mathrm{a}$ & $0.88 \mathrm{~b}$ & $0.83 \mathrm{a}$ & $0.84 a$ & $1.29 \mathrm{a}$ & $56.50 \mathrm{a}$ & $57.10 \mathrm{a}$ \\
\hline $3 \mathrm{kGy}$ & $0.53 \mathrm{c}$ & $0.57 \mathrm{C}$ & $0.74 \mathrm{c}$ & $0.57 \mathrm{a}$ & $0.94 \mathrm{c}$ & $0.83 \mathrm{a}$ & $0.86 \mathrm{a}$ & $1,36 \mathrm{~b}$ & $55.93 \mathrm{a}$ & 59.37 b \\
\hline
\end{tabular}

Values within a column followed by the same letter are not significantly different at the $96 \%$ confidence level. 
Table VII

Effect of gamma irradiation on $\mathrm{pH}$ value in washing water and brine of olive fruits

\begin{tabular}{|c|c|c|c|c|c|c|c|c|c|c|}
\hline \multirow{2}{*}{ Treat. } & \multicolumn{8}{|c|}{ Washing water (day) } & \multicolumn{2}{|c|}{ Brine } \\
\hline & ist & $2 \mathrm{nd}$ & $3 \mathrm{rd}$ & 4th & 5 th & 6 th & 7 th & 8 th & 6 menths & 12 months \\
\hline Control & $5.70 \mathrm{~b}$ & $5.23 \mathrm{a}$ & $5.13 \mathrm{a}$ & $5.02 \mathrm{a}$ & $4.75 a$ & $4,71 \mathrm{a}$ & $4.65 \mathrm{a}$ & $4.24 \mathrm{a}$ & $5.97 \mathrm{ab}$ & $5.71 \mathrm{a}$ \\
\hline $1 \mathrm{kGy}$ & $5.71 \mathrm{~b}$ & $5.27 \mathrm{a}$ & $5.28 \mathrm{a}$ & $4.92 \mathrm{a}$ & $4.82 \mathrm{ab}$ & $4.77 \mathrm{ab}$ & $4.81 \mathrm{~b}$ & $4.38 a b$ & 5.93 a & $5.81 \mathrm{a}$ \\
\hline $2 \mathrm{kGy}$ & $5.64 \mathrm{a}$ & $5.32 \mathrm{a}$ & $5.28 \mathrm{a}$ & $4.96 \mathrm{a}$ & $4.95 \mathrm{~b}$ & $4.90 \mathrm{~b}$ & $4.85 b$ & $4.41 \mathrm{ab}$ & $6.00 a b$ & $5.80 \mathrm{a}$ \\
\hline $3 \mathrm{kGy}$ & $5.75 \mathrm{c}$ & $5.31 \mathrm{a}$ & $5.24 \mathrm{a}$ & $4.92 \mathrm{a}$ & $4.90 \mathrm{ab}$ & 4.82 ab & $4.84 \mathrm{~b}$ & $4.51 \mathrm{~b}$ & $6.17 \mathrm{~b}$ & $5.71 \mathrm{a}$ \\
\hline
\end{tabular}

Values within a column followed by the same letter are not signiticantly different at the $85 \%$ confidence level.

\section{DISCUSSION}

Gamma irradiation at used doses (1,2 and 3 KGy) increased total and inorganic dissolved solids, ( $\mathrm{Na}$ and $\mathrm{K}$ ) in the washing wastewater and brine of irradiated olive fruits. This increase might be due to several factors; 1 )- degradation of cell wall fiber components (cellulose, legnin, hemicellulose, pectin, etc...) of fruit skin, which may have increased its permeability. The evidence concerning the effect of irradiation on olive fruits is not available in the literature. However, a lot of data is reported on other fruits Kertesz et al, (1964) suggested that both cellulose and pectin of apple fruits were degraded by gamma irradiation at the same threshold doses. Muhamad (1990) found that irradiation with 1.0 and 1.5 KGy slowed down the reduction rate of alcohol insoluble substances, hydrochloric acid soluble pectin and the increment of water soluble pectin and the hexamataphosphate soluble pectin in papaya fruits. Xin-Zhi-Jiao (1989) reported that under the electron microscope, the cellulose in the cell walls of apple fruits seemed to be reduced to a line when treated with $0.4 \mathrm{kGy}$ gamma radiation for $38 \mathrm{hr}$, and disappeared completely after treatment with $1 \mathrm{kGy}$. Amour et al., (1993) found that cell wall polysaccharides, particularly cellulose and pectin. were partially degraded when strawberry fruits were irradiated by 4 kGy. The effect of low doses of gamma irradiation was also observed by Drake et al., (1994) on cherries irradiated by 0.4 and $1.0 \mathrm{kGy}$; Miller and McDonald (1994) on apple irradiated with 0.3 kGy: and by Al- Bachir (1999b) on apples irradiated by $0.5,1.0$ and $1.5 \mathrm{kGy}$. 2)- changing the storage components of fruit from nonsoluble to soluble forms Yasia et al., (1987) reported that irradiation increased hexametaphosphate soluble pectin (HMP). 3)increasing some enzymatic activities that may contribute to the degradation of cell wall structure components. Al-Bachir (1986) found that $1.0 \mathrm{KGy}$ of gamma irradiation increased the activity of pectin methyl esterase (PME) in apple and pear fruits.
These reported information on different fruits may suggest that a similar effect could have happened in olive fruits leading to increasing the organic and inorganic dissolved solids, ( $\mathrm{Na}$ and $\mathrm{K}$ ) in the washing wastewater and brine. This increase of solids in washing wastewater and brine may have increased the $\mathrm{pH}$ and $\mathrm{EC}$ values of those solutions.

\section{CONCLUSION}

Our results indicated that gamma irradiation increased degradation of the big molecules in olive fruits, changed insoluble components to soluble forms and increased the permeability of Surrany olive fruit cell walls. These changes may help the debittering. suggesting that gamma irradiation could be used as an alternative debiterring method. However, this needs further investigation.

\section{ACKNOWLEDGMENTS}

The author wishes to express his deep appreciation to the Director General of Atomic Energy Commission of Syria for his support and encouragement.

\section{REFERENCES}

Al-Bachir, M. (1986), Az ionizalo sugarzas hatasa a gyumoics- telek es csemegeszolo tarolhatosagara. (Effect of ionizing irradiation on storability of fruits and grapes). Kertiszeti egyetem, Kandidatusi ertekezes. Budapest.

Al-Bachir, M. (1998). Use of gamma- irradiation and sulphur dioxide to improve storability of two Syrian grapes cultivars (Vitis vinifera). International Journal of Food Science and Technology, (33) pp. 521-526.

A.-Bachir, M. (1999a). The effect of gamma- irradiation on storability of two cultivars of Syrian grapes (Vitis vinifera). Fadiation Physics and Chemistry, (55) pp. 81 . 85 . 
Al-Bachir, M. (1999b). Effect of gamma- irradiation on storability of apples (Malus domestica L.). Plant Food for Humman Nutrition, (54) pp. 1- 11.

Amour, Jd., Gossel-in, C., Arul, J., Castaigne, F. and Willemot, C. (1993). Gamma-radiation affects cell wall composition of strawberries. J. of Food-Science, V.85 (1) pp.182-185.

Annual Agricultural Statistical Abstract, (1999). Syrian Arab Pepublic, Ministry of Agriculture and Agrarian Reform, Dep. Of Planning and Statistics, Division of Agricultural Statistics, Production \& Numbers of Olives Trees, 1990-1999 by Govemorate 1999, Table 78.

Anonymous (1994). Situacion y evolucion del mercado internacional de la aceituna de mesa. Olvvae, 54, pp.18-21.

Association of Official Analytical Chemists (AOAC) (1990). Official methods of analysis (15th ed.), Washington, D. C., U.S.A.

Cserep, Gy, Jejes, P., Foldiak, G., Gyorgy, L., Horuath, Zs, Jakab, A., Stenger, V. and Woinarovits, L. (1971). Chemical dosimetry course: a laboratory and institute of isotopes of Hungarian Academy Sciences, Budapest, pp. 27-32.

Drake- SR., MoHtitt- HR., and Eakin- DE. (1994). Low dose irradiation of Rainier sweet cherries as a quarantine treatment. J. of Food Processing and preservation, V. 18 (6) pp. 473- 481

Fernandez Diez, M. J. (1984). Changes in the chemical components during the processing of table olives and their relation to the quality, in proceedings of the IUFOST international symposium, Vol, I, Valencia, Spain, November 5-7, pp, 301-18

Fernandez Diez, M. J. (1991). Olives, in Encyclopedia of Food Science and Technogy, Vol. 3 (ed Y.H. Hui), Wiley \& Sons, New York, pp. 1910-25.

Fernandez Diez, M. J., Castro Ramos, R., Garrido Fernandez, A., Gonzalez Cancho, F., Gonzalez Pellisso, F., Nosti Vega, M., Heredia Moreno, A., Minguez Mosquera, M. I., Rejano Navarro, L., Duran Quintana, M. C., Sanchez Roldan, F., Garcia Garcia, P., and Castro Gomez Millan, A. (1985). Biotecnologia de la aceituna de mesa. Consejo Superior de Investigaciones Cientificas, Instituto de la Grasa, Madrid-Sevilla, Spain.

Garcia, P., Brenes Balbuena, M., Vicente Gonzalez, J. and Garrido Fernandez, A. (1990). Depuracion de las aguas residuales de las plantas envasadoras de aceitunas verdes mediante tratamientos fisico-quimicos. Grasas y Aceites, 41, pp.263-9.

Garrido Fernandez, A. (1982). New wastewater free process to produce Spanish green olives, in Proceedings of International Symposium on Food Industries and Environment, Budapest, pp. 107-14.

International Olive Oil Council (IOOC) $(1960-1990)$, yearly reports on production of table olives, IOOC, Madrid.

Kertesz, Z. I , Glegg. R. E., Boyle, F. P., Parson, and Massey, L. M. Jr. (1964). Effect of ionizing radiation on plant tissues III. Softening and change in pectins and cellulose of apples, carrots and beets, J. Food Sci. pp. 29-40.

Miller- WR and McDonald- RE (1994). Quality of preharvest GA3- treated grapelruit after gamma irradiation and storage. Proceedings- of- the-FloridaState - Horticultural Society, V. 107, pp, 232-234.

Muhamad- Samadi-bin-Yasir (1990). The eflect of gamma radiation on the chemical content, texture and shelf life of papaya. J. Sains-Nuklear-Malaysia. V. 8 (1) pp.15-23.

Xin- Zhi- Jiao (1989). The eflects of gamma- ray ultrastructure and ethylene biosynthesis in apple pulp cells. Plant- Physiology, Supplement. V. 89 (4) pp. 194.

Yasia, - M. S., Chachin, - Kazuo and Iwata, - Takashi (1987). Effect of gamma irradiation on tissue firmness, some cell wall degrading enzymes and pectic substances of tomato fruit. Bulletin- of- University- ofOsaka- Pretecture, Series- B- Japan. V. 39, pp. 9-20.

Recibido: Octubre 2000 Aceptado: Junio 2001 